\title{
Organizing and innovating in poor places
}

\section{Introduction}

Poor places are where the innovation rubber really hits the road. Across the globe millions of localised social, public and private organizations strive to find new solutions to social problems which are up close and personal. Innovation has been described as the means through which organizations 'thrive and survive' (Dodgson, Gann \& Philips, 2014); in poor places the survival of the people they serve can depend on it. Unsurprisingly, working in places with constrained socio-economic resources presents numerous challenges to managing innovation, yet innovation often flourishes. The drivers to innovate are diverse but include necessity, a response to unmet needs, a shared vision of what could be, and achieving legitimacy in the eyes of external power and resource brokers. The resulting innovations may be life changing or provide a bulwark against further erosion of socio-economic conditions. They may be disruptive and provide replicable models for others. Equally, they may be flawed, precarious, or simply unachievable given capacity and unforgiving contexts. They may well be misguided or, at worst, make life even more difficult. In other words, innovation in poor places is simultaneously necessary, challenging, and has real consequences in localities where there is little margin for error.

Organizational innovation in poor places is a fascinating, if somewhat overlooked, area of innovation research. It raises inherently interesting questions such as how do organizations situated in poor contexts design innovation and then garner and mobilise resources? What organizational and inter-organizational forms and action facilitate, hinder or destroy innovation? Do innovations 'stick', enhance and transform poor places, or merely provide a brief yet unsustainable respite? And can relatively powerless micro actors make a difference to macro problems? These questions are not only fascinating, they are pressing. 
First, the social, economic and environmental issues that challenge us all invariably impact poor places significantly more than other areas; poor places tend to be the loci of the concentrated externalities of globalisation, from de-industrialization in the global north to industrialization in the global south. Even relatively small shifts in circumstances expose socio-economic fragility, as living on the margins is inherently stressful and the prospect of change may be threatening - poor places can be 'fragile, fraught and fearful' (Stott \& Longhurst, 2011, p.103). Second, the onus to make change in poor places appears to be shifting from the state to local actors - the downloading of 'risks and responsibilities against a backdrop of austerity' (Crisp, Pearson \& Gore, 2015, p. 182). In other words, precariousness mediated by 'community' rather than state action. Although this may not be new in much of the global south, in many Western countries it is producing a new geography of inequality. The idea of de-centralised governance and localities solving their own problems resonates with cash struck states, neo-liberal agendas, and advocates of participatory development (Warren \& Visser, 2016; Wills, 2016).

While the institutional and socio-economic context of poor places varies across the globe (e.g., the stark contrasts between places experiencing relative and absolute poverty), there are also similarities in the organizational landscape which shape approaches to innovation within them. As we will see, not all organizational innovation in or focused on poor places is necessarily beneficial. Most are served to a lesser or greater degree by a range of organizations, from local to supra-national, across the public, social and private sectors as well as a myriad of informal organizations, both legal and criminal. In other words, no place is an island of purely local organizations.

Organizations in poor places tend to provide, protect, patrol or predate. With regard to provision, products and services are sold or distributed, although given the low disposable incomes that are a defining feature of poor locales, the nature of the products and services are 
often different to those available in more affluent places (e.g., greater reliance on discount products or geared services such as anti-poverty programmes). Increasingly, poor places are perceived as 'Bottom of the Pyramid' markets (Prahalald \& Hart, 2002) or 'shared value' (Porter \& Kramer, 2011) opportunities for innovative companies, as well as the sites of multiple interventions to provide welfare.

Numerous organizations also seek to protect poor places from economic change, crime, exploitation (human or environmental), and disease. Equally, organizations (including some of those pertaining to protect) patrol poor places - often using coercive or punitive means - to curb or contain behaviours, or set boundaries to curb or contain people. Indeed, from the Victorian/US progressive era of 'social explorers', organizations of different types have mixed protection with patrolling interventions. This reflects, perhaps, the uneasy relationship that most societies have with poor places and their inhabitants. Notions of degeneration, contagion (medical and moral), the deserving or un-deserving poor, and the poor as underclass or precariat are frequently used to describe 'deprived' places. Such places have attracted an inordinate amount of attention which vacillates between pity and vilification (Jones, 1984/2013; Macek, 2006; Stott \& Longhurst, 2011). They are often connected with moral panics about, for instance, juvenile delinquency and teenage pregnancy. For example, in the UK the 'troubled' families programme focused overwhelmingly on people living in poor places.

Finally, organizations also predate - they exploit vulnerable people and local resources. Obvious predations include organised crime within poor places such as drug dealing, sexual exploitation, illegal money lending, and human trafficking. Less obvious are the predations of 'legitimate' pay day loan companies, banks and hire purchase companies that apply higher interest rates in some postal codes than in others. Predation also includes the sale of adulterated or contaminated goods from food to tobacco products. Social purpose 
organizations are not immune from charges of predation. For instance, Alinsky criticised the 'welfare colonialism' of the 'social welfare industry' and local state, which siphoned or redirected resources away from grassroots organizations during anti-poverty initiatives (1965, p. 46) - a charge since laid at public and social organizations who 'parachute' into poor places and disappear once funded programmes cease. More recently, Hatcher (2016) argued that a 'poverty industry' has emerged with an 'iron triangle' of the national state, local state and private contractors, with the local state shifting funds from federal aid to general revenue and private contractors 'strip mining' profit from programmes.

Understanding the landscape, context and impact of organizations in providing, protecting, patrolling or predating is key to understanding the tensions and contradictions, as well as possibilities, of social innovation in poor places. In the next section we outline the main debates relating to poor places in the organizational and innovation literatures, which include social and community entrepreneurship, as well corporate approaches to addressing poverty and inequality.

\section{Social innovation in poor places: an overview of current thinking}

Van der Have and Rubalcaba (2016) suggest that social innovation is an emerging area within innovation studies and highlighted clusters of scholarly activity including a focus on social and societal challenges and local inclusive development. We outline three main themes. First, a dominant theme in the social innovation literature is that of social entrepreneurship. The challenge of combining elements from the profit and non-profit spheres to achieve financial and social missions simultaneously, particularly in poor contexts, has fascinated scholars who have approached the problem through multiple lenses including that of hybridity (e.g., Battilana, \& Dorado, 2010; Battilana \& Lee, 2014; Smith, Gonin \& Besharov, 2013), bricolage (e.g., Di Domenico, Haugh, \& Tracey, 2010) paradox (e.g., Smith, Besharov, 
Wessels \& Chertok, 2012), and business model innovation (e.g., Mair, Battilana \& Cardenas, 2012). Others have examined the apparent inability of many social enterprises to grow and the traumatic failure of much heralded ventures (Tracey \& Jarvis, 2006), the relationship between organizational stigma and social enterprise (Tracey \& Philips, 2016), and 'collective social entrepreneurship' involving organizational collaboration within and across sectors (Montgomery, Dacin \& Dacin, 2012). Related work on institutional voids has examined the role of social innovators in overcoming barriers to market participation in Bangladesh (Mair \& Marti, 2009) and the role of institutional support from corporate and public agencies in creating the conditions for social entrepreneurship (Stephan, Uhlander \& Stride, 2015).

A second dominant theme in the social innovation literature is community entrepreneurship, although interest in the concept has waned somewhat in light of the rise of - one might even say obsession with - social entrepreneurship. But while less prominent than social entrepreneurship in management research, community entrepreneurship can in fact be seen as an organizational precursor to it (Bailey, 2012; Pearce, 1993). Peredo and Chrisman (2006, p. 310) suggest that 'community-based enterprise' is a process whereby local actors create organizations 'embedded in existing social structures', act collectively for the common good, and work to find novel solutions to local problems in the context of - often severe resource constraints. For Haugh (2007) community ventures have an important role in overcoming market or state failure, while Sommerville and McElwee highlight the resource tensions that emanate from being 'rooted in place' as well as the expectations to be inclusive of local stakeholders (2011, p. 325). In the context of the global south, researchers have sought to shed light on indigenous community enterprise (e.g., Giovannini, 2014; Peredo, Anderson, Galbraith, Honig \& Dana, 2004), value creation through eco-tourism or conservation, local market development (e.g., Warren \& Visser, 2016) and corporatecommunity partnerships (e.g., Nwankwo, Phillips \& Tracey, 2006). 
A third main theme in the emerging social innovation literature focuses on the role of for-profit firms in addressing social problems. Most obviously, there is a long tradition of research on corporate social responsibility (CSR). With some notable exceptions, this work has tended to concern itself with the motivation and firm-level consequences of socially responsible behaviour (MacGregor, Fontradona \& Hernandez, 2010; Preuss, 2011). However, debate on the role of corporations in poor places appears to be shifting away from the concept of CSR, to a focus on how firms can achieve innovative social outcomes. Underpinning this shift, in part, is a belief that corporations may be the only actors with the resources and innovative capacity required to solve the world's most intractable problems with respect to poverty, inequality and environmental degradation (Dunfee \& Hess, 2000). Specifically, Kanter (1999, p. 124) highlighted the emergence of a corporate social innovation 'paradigm', which helped to precipitate a 'sparse but growing' literature (Herrera, 2015, p. 1468) on, for example, cross-sector collaboration, ethical supply chains, and strategies to cater for Bottom of the Pyramid (BoP) consumers (Mirvis, Herrera, Googins \& Albareda, 2016).

Indeed, a rush to the BoP followed Prahalad and Hart's (2002) argument that the poor actually represented a source of huge untapped profit - by adapting product offerings for low margins and high volumes, companies could not only generate significant revenues, they could lift billions of the poor out of absolute poverty (Prahalad, 2004). However, enacting a BoP strategy may not be as unproblematic as its proponents suggest. For example, a number of firms have attempted to mimic Unilever's success in selling detergent in India with a focus on other household products. Many have failed to achieve profitability despite the resources at their disposal - the lack of pre-existing distribution and retail infrastructures as well as a lack of familiarity with the products themselves in target markets represent significant barriers (Simanis, 2012). The BoP concept has also come under increasing ethical scrutiny (Ansari, Munir, \& Gregg, 2012). While corporations operating at the BoP often play a key 
role in getting affordable health, housing, food and educational products to poor places, the morality of profit maximisation in such contexts sits uneasily with some. For example, Arora and Romijn (2011, p. 482) suggest that the BoP is a 'discursive curtain' which hides power relationships, provides 'social legitimacy to further corporate accumulation and expropriation', and sidelines 'the controversial experience' of business in development.

In sum, in this section we have outlined the key debates relating to innovation and poor places, focusing on social entrepreneurship, community entrepreneurship, and the role of corporations. With some exceptions (such as work on indigenous community entrepreneurship), we suggest that much of the work outlined above either emphasises the passivity of poor places and people, or focuses on the actions of heroic individuals or organizations. Moreover, in focusing primarily on civil society organizations and corporations, the role of public bodies in innovating in poor places has been largely neglected. In the next section, we outline some contemporary trends in social innovation practice in poor places and suggest a research agenda.

\section{Moving forward: A research agenda for place based social innovation}

An important question, in our view, is the following: how can innovation scholarship contribute to the practice and impact of organizational innovation in poor places? Moreover, how can organizational researchers' gaze move from 'designing a better machine in the interests of those it serves rather than those it damages' (Clegg, 2009, p. 344) and rise to Starbuck's (2003) challenge to contribute in a meaningful way to human welfare? By and large, the innovation literature is largely focused on the for-profit firm and creating economic value first and foremost. While numerous insights can be incorporated from this work and applied to organizational innovation in poor places, the 'fit' is not always comfortable or appropriate to the nuances of delivering social value, let alone social and economic value 
simultaneously, in diverse and challenging institutional contexts. Researchers can also turn to the burgeoning social innovation literature, yet this is still in its infancy and research remains emergent - not least in terms of building theory about the role of place (for a discussion see Tracey \& Stott, 2017)

In light of these issues, in this section we develop a research agenda for social innovation in poor places. We structure our agenda around research opportunities focused on: 1) the social sector, 2) the public sector, 3) the corporate sector, and 4) cross-sectoral approaches. We use 'sectors' as an organizing framework for our agenda because policy and practice is often planned and executed by actors who perceive the organizational landscape in such terms. We are aware that conceptualizing social innovation in terms of sectors is not without its drawbacks - it reifies boundaries between different types of organization which can hinder collaboration, and privilege particular approaches over others. We will revisit this issue when we consider the role and potential of cross-sectoral approaches.

\section{Social purpose organizations and place-based social innovation}

Social entrepreneurship, the process of creating and growing a venture to tackle social challenges, is rapidly becoming the 'go to' strategy for policy makers and those seeking to create social change. However, there is a 'lag' between research and practice (Stephan, Uhlander \& Stride, 2015), therefore we suggest there are several trends which merit further investigation. First, social enterprise is often portrayed as a means to overcome state and/or market failure in poor places (e.g., Haugh, 2007). It assumes localised social enterprise can ameliorate, amend or provide alternatives to the harm that results from structural socioeconomic change in poor places through the creation of sustainable ventures. Furthermore, social enterprises are often assumed to have 'restorative powers' and to be destined to become a 'mainstay of future social organization' (Amin, Cameron \& Hudson, 2002, p. vii) - 
which appeals to states and social entrepreneurs alike. Social entrepreneurship advocates (and their community entrepreneur predecessors) have long imagined creating alternative (or parallel) social economies within poor places for a myriad of reasons, not least as the harbingers of a kind of conscious capitalism, socialism or sheer pragmatism in the face of pressing social need.

Contemporary policy, practitioner and academic literature often reinforces the idea that social enterprise is the answer for social ills. Gibson-Graham, Cameron and Healy (2013), for example, urge us to 'take back the economy' by creating a just and environmentally sustainable community economy, while Mintzberg (2015) argues that only the 'plural sector' (by which he means the social or third sector) can kick-start radical renewal - he argues provocatively that the state is essentially co-opted by the private sector and the notion of CSR cannot compensate for what he terms 'corporate social irresponsibility'. Whatever the motivation, the problem remains: can social entrepreneurship overcome market or state failure? We suggest not. At least not alone. We believe that the weight of expectations placed on social entrepreneurship to overcome others 'failures' is at best unhelpful and at worst counterproductive, not least because sustaining social enterprises appears to be inherently difficult. The research discussed above suggests that there is a gap between what is possible and what is imagined, particularly in poor places. A better understanding of the role and impact of social entrepreneurship in overcoming market or state failure is long overdue, and social innovation researchers could play a key role in this respect.

Second, state actors in the global north increasingly perceive social entrepreneurship as an alternative to expensive public welfare - a way of shifting responsibility for local solutions to local actors, or encouraging novel solutions where all else seems to have failed. Social entrepreneurship, therefore, is seen as 'the only game in town' for many social purpose organizations as public funding becomes scarce (Dey \& Teasdale, 2015). The impact of a 
'roll back neo-liberalist' or 'post welfare approach' (DeVerteuil, 2015) to poor places has resulted in less direct public funding and less indirect support from local agencies. While the retreat of the state from the provision of universal services predates the financial crash of 2008, subsequent intensifying waves of public sector austerity appear to be changing the relationship between state and citizen in many countries - in the state's mind at least. The externalities of austerity are felt the most in poor places. It appears that if the poorest actors want services they must turn to social enterprise models without the infrastructure which supported the earlier wave of social enterprises in the preceding two decades. Thus we suggest that social entrepreneurship in the context of deepening public austerity is an area for urgent attention.

Third, in the global south, Western models of social enterprise are vigorously promoted by foundations, NGOs and state agencies ('an idea whose time has come' according to the British Councili ${ }^{\mathrm{i}}$ ) to regimes one might not expect to be receptive, such as Vietnam and China. There is a burgeoning practitioner literature which describes and celebrates the spread of social enterprise. With the notable exceptions of individual case studies (such as Smith, Leonard \& Epstein, 2007), there is little rigorous inquiry into the emergence of social entrepreneurship within what was assumed to be hostile environments, and the exercise of 'soft power' on the part of Western governments and NGOs in this process. There is also little work on the role of the state in withholding, providing, or imposing institutional support (see Hildebrandt, 2013 for an intriguing discussion on the rise of, and constraints on, NGOs in China).

Fourth, there is little sign of interest in social enterprise across the globe abating, or sobering research (such as Amin, Cameron \& Hudson, 2002) denting the zeal of a new (and relatively un-researched) wave of social entrepreneurship. This is due, in part, to strong isomorphic pressures rooted in the ever-increasing legitimacy of social enterprise, the rise of 
social entrepreneurship education, social incubators, social innovation competitions, and the 'carrot' of social finance combined with 'stick' of public austerity. The recent 'social entrepreneurship turn' incorporates a broad yet disparate range of organizations and individuals. There is a surge in individuals or small teams with very personal motivations and particularistic solutions to issues they perceive as important. It appears to be primarily a professional and middle class phenomena which resonates particularly with young elites who want to give back to society (Power, Allouch, Brown \&Tholen, 2016) or are fascinated by digital or so-called design-led solutions to social problems. In some countries, social entrepreneurship may be the only legitimate means of creating opportunities for social change or engaging political action. While young elites revel in social enterprise, are increasingly sophisticated in their business models and often attractive to both social and 'mainstream' finance, we see social enterprise as a vibrant yet inchoate approach whose potential and impact is unproven. We echo Amin, Cameron and Hudson's concerns that we face 'a return to the vagaries of 'good acts' and 'good people') (2002, p. x) rather than systemic solutions. However, the motivations, aspirations and innovation practices of this generational wave of social entrepreneurs is under-researched and theorised.

Finally, social entrepreneurship focused on poor places tends to be, at best, 'done with', more often 'done to' and to a lesser extent, 'done by' poor people. If poor places are perceived as being in deficit (for instance in resources, time and leadership), 'done to' approaches tend to predominate even if the goal is to stimulate local capacity. This includes ventures like TOMS who provide the 'gift' of shoes, water, safe births and eye care ${ }^{\mathrm{ii}}$. Moreover, outsiders are seen as catalysts who can innovate to circumvent local norms and practices, overcome inertia or lack of trust in local institutions. 'Done with' is where outsiders partner and 'co-produce' solutions which are sensitive to the local context and provide the capacity to innovate. It builds on the 'asset-based' approach, where poor places 
are seen as having latent potential as well as untapped financial, environmental or human resources (Green \& Haines, 2015). For instance, Under the Mango Tree ${ }^{\mathrm{iii}}$ promotes beekeeping as income generation and provides routes to market for 'marginal' honey farmers in India which, in turn is supported by Village Capital ${ }^{\text {iv }}$ that targets social ventures in 'underserved' areas globally to create new products and services. 'Done by' is a bottom up, 'self-actualisation' approach to solving local needs which emphasises micro innovative responses to macro change to achieve a degree of economic stability and a 'buffer' between the local and the global through community control and ownership of capital (Imbroscio, Williamson \& Alperovitz, 2003). Recent initiatives echo the 'good acts' and 'good people' format such as Power to Change, ${ }^{v}$ which focuses on reviving assets and protecting services through community business such as pubs, shops, libraries and community centres - all services the public or private sector struggle to sustain. The model depends on localised ownership (through shares) and sales, which presents numerous challenges when operating within poor places. Interesting questions remain to be addressed on how 'self-actualised' social enterprise is stimulated, the organizational forms that sustain it, and the role of intermediaries in supporting it.

The distinct role of community-based social purpose organizations

So far in this section we have outlined some possible research opportunities for the study of social purpose organization with respect to social innovation in poor places, with a particular focus on social enterprise. However, as noted earlier, there are a range of community-based social purpose organizational forms, many of which predate social enterprise. These are often overlooked by innovation researchers, but we think they are very important. We therefore include a subsection which specifically focuses on the distinct role of community-based social purpose organizations, and the implications for those who study them. 
We believe that the rather neglected discourse on community-based social purpose organizations offers innovation scholars a rich vein of research opportunities that could reinvigorate the practice and potential of social innovation in poor places. They are particularly interesting because they tend to represent 'done by' approaches to social change, with people in poor places seeking to take control of their destinies. Take cooperatives, for example. The movement has spread across the globe and it has a history that spans over two centuries. It is a somewhat forgotten history, but it features an organizational form with a strong track record of delivering social impact and financial sustainability simultaneously. Many of the challenges facing contemporary social innovators have been experienced time and time again by cooperatives, and there is a fascinating opportunity to learn from them. For instance, many local UK cooperative societies in the $19^{\text {th }}$ and $20^{\text {th }}$ centuries developed holistic solutions to tackle acute social needs (Robertson, 2016). The Desborough Cooperative Society's portfolio included brick and tile making, iron ore mining, farming, allotments and housing. It also provided a savings bank, leisure and educational services and 'co-partnerships' with other cooperatives (Sanders, Marlow \& Marlow, 1913). This approach stemmed from the lessons of earlier experiments which failed such as 'Exchange Bazaars' where goods were swopped among workers, and 'Equitable Labour Exchanges' which aimed to reward workers on the basis of their skill and effort (Cole, 1944, p. 25). While innovative, many struggled to embed the innovation and become sustainable, in part due to the lack of business experience (Wilson, Webster \& Vorberg-Rugh, 2013). Nonetheless, cooperatives constantly innovated to weather macro storms, local impacts, and commercial failures. Crucially, it was a movement which provided a core philosophy, theory of change, mutual support and operated at scale - which is far removed from much contemporary social entrepreneurship. 
Another overlooked 'done by' model is community economic development (see Haugh 2007 and Peredo and Chrisman 2006 for notable exceptions). Prior to the rise of social enterprise discourses in the 1990s, the community enterprise movement developed placebased strategies which challenged 'atomistic' neo-liberal interventions and privileged collective approaches (Imbroscio, 1997, p. 106). Building on cooperative forerunners, community development corporations (CDCs) sprung up in the USA's poorest neighbourhoods during the 1960s where they delivered holistic community owned solutions to pressing needs through social, housing and economic development programmes - initially supported through the activities of the Ford Foundation. Characterised as anchor organizations who build community capital (social, financial and physical) and aim to have a sustainable long term relationship with a place (Stott, Stott \& Wiles, 2009, p. 19), CDCs have a fifty-year history of innovation of operating in the face of adversity, with considerable successes as well as numerous failures (Halpern, 1995; Twelvetrees, 1996). Rather surprisingly, CDCs have received 'short shrift' in the academic literature (Costa, Pickering \& Bernheim, 2014, p. 5) - as have the UK equivalent, Development Trusts. Again, CDCs represent an organizational model whose history and current practices can shed much needed light on what works and what does not work in poor places. As Selznick (1957) reminds us, such organizations can become institutions infused with value and garner extraordinary local support. Moreover, like cooperatives before them, CDCs and Development Trusts have built intermediary organizations 'to create new replicas of themselves both as converted individuals and organizations based on belief' - a form of 'evangelical isomorphism' (Stinchcombe, 2002, p. 415). We find organizations like CDCs, Development Trusts and cooperatives especially interesting because they provide an opportunity to examine how place-based social purpose organizations innovate and sustain their missions as the fortunes of their communities' wax and wane. 


\section{The public sector and place-based social innovation}

We find it surprising that the public sector has been so neglected in the mainstream innovation literature given its major role in local, national and international interventions to support innovation in general and poor places in particular (Mazzucato, 2015). There have been innumerable public programmes across the globe targeted at poor places which have aimed to make systemic change. When mobilised to tackle social injustice, the state has shown, at times at least, that is has the capacity to be both innovative and reasonably effective. However, as global inequality becomes more pronounced and with the rise of austerity in the global north, ambitious systemic interventions are in short supply and the state often turns to others to innovate.

This is not to say that the public sector is an innovation wilderness. As they struggle with decreasing resources, there has been a surge of new initiatives. For example, there has been a sharp rise in the number of public social innovation labs around the world, which seek to involve staff and citizens in reengineering or co-producing services. Equally, there has been a turn to behavioural science and 'nudge' initiatives to make services more cost effective, easier to use, enable people to make better choices through a 'more realistic model of human behaviour' according to the UK's Behavioural Insights Team ${ }^{\mathrm{vi}}-$ an approach rapidly mimicked by other nation's public agencies (Halpern, 2015). Another approach sweeping the public firmament is that of 'community resilience,' which draws on ideas as diverse as ecology, engineering, psychology, and management (Berkes \& Ross, 2013; Vogus $\&$ Sutcliffe, 2007). For instance, the Rockefeller Foundation funded the 100 Resilient Cities global programme, which incorporates action on major shocks or disasters, as well as day-today stresses such as unemployment, violence and resource shortages ${ }^{\mathrm{vii}}$. The emergent community resilience policy literature is infused with social innovation language intertwined with austerity discourses urging staff and citizens to action (for example see Cambridgeshire 
County Council, 2015). There is pressing need for research on the adoption, diffusion and impact of policy initiatives such as 'nudge' and 'community' resilience on poor places (Ross \& Berkes, 2014), not least because concepts and practices which are relatively untested often gain traction and end up being transplanted in poor places without sufficient understanding of their effects or effectiveness - a worrying example of mimetic isomorphism (DiMaggio \& Powell, 1983).

Yet another neglected form of public social innovation is the creation of local public enterprises to meet needs - enterprises which are owned by the public sector to deliver social and economic returns. Faced with industrialising cities, swelling populations, poor sanitation and disease, social reformers in nineteenth century England sought to counterbalance what they viewed as the excesses of capitalism through purchasing or building municipal assets Liverpool docks and Manchester gasworks for instance. The most famous example was in Birmingham where Joseph Chamberlain persuaded the council to purchase two gas companies. While local democracy and managing the 'excess' of private companies was part of his agenda, making a surplus to offset rising city debt was also a prime motivation. The municipalisation of sewers and water soon followed, which led to significant improvements in public health. Later, the city embarked on the mass purchase of housing in order to address the squalid living conditions of a significant proportion of its inhabitants (Geherke, 2016). In the USA, public enterprise at all levels of government has blossomed since the 1930s, and vast numbers 'now constitute a quasi-governmental sector that in some dimensions dwarfs general-purpose government' (Radford 2003, p. 864). The US model of public enterprise perhaps surprisingly for a country known as the bastion of the 'free market' - is relatively uncontested across the political spectrum, although this may be partly because of a lack of transparency with respect to the governance arrangements in place. Nonetheless, the evidence suggests that public enterprise in the US often delivers key services very effectively, while at 
the same time generating significant returns to the public sector. Imbroscio (1997) suggests the local state mirrors community economic development through building asset portfolios to extract rent, direct municipal ownership, hold equity in private enterprises, as well as buying and selling assets to deliver short term returns. For Radford, however, a key shortcoming of public enterprise can be a lack democratic control and accountability. She argues for 'new and unconventional forms of public economic activism,' which may well include 'traditional' public enterprises but also social-public sector hybrids (Radford, 2013, p. 166).Contemporary public sector enterprise, in the USA in particular, provides a significant opportunity to build understanding about how the state translates innovation practices from corporate organizations (as well as developing sector-specific innovations such as in governance) for the public good.

\section{Corporate organizations and place-based social innovation}

While there have be recent attempts to reframe CSR within the innovation literature, outlined in the previous section, CSR itself has become somewhat tarnished (Mahoney, Thorne, Cecil \& LaGore, 2013). It is clear that the extent to which firms say they practice CSR has increased significantly over the past two decades. Two main explanations have been put forward. One is that firms who invest in CSR reporting are simply seeking to signal to stakeholders that they are genuinely 'good' corporate citizens (Mahoney, Thorne, Cecil \& LaGore, 2013). The other is that firms are under pressure to be seen to be socially responsible, and so exaggerate both the extent to which they are engaged in and the effectiveness of their CSR initiatives. In other words, they practice green or social washing. Despite such the concerns, it seems clear that CSR, when performed well, can make a significant difference to hard pressed communities and social organisations. 
However, perhaps a more promising approach is when firms focus on the social context and supply chain relationships in which firms are embedded - i.e. the ecosystem in which it operates (Carter \& Rogers, 2008). In other words, focusing on doing core business to higher and higher social and environmental standards which are inclusive and avoid the weight of corporate externalities falling on poor places. While still in its theoretical infancy, corporate social innovation which includes integrating ideas around social innovation, inclusive growth, and ecosystems arguably offers much potential and deserves the attention of researchers. The focus of research to date has been on the big corporates, but as Hockerts and Wüstenhagen (2010) suggest, it is often the Davids not the Goliaths which lead the way on social and environmental innovation, and therefore the Davids merit further attention

Another promising stream of research, which emerged partly as a response to the criticisms of the BoP concept, has emphasized the notion of inclusive innovation, defined as 'the development and implementation of new ideas which aspire to create opportunities that enhance social and economic wellbeing for disenfranchised members of society' (George, McGahan \& Prabhu, 2012, p. 663). Concepts such as jugaad (makeshift) and frugal innovation are core to the notion of inclusive innovation, and a key difference of emphasis between such approaches and BoP innovation is their focus on the involvement of members of the target community in the innovation process (Radjou, Prabhu \& Ahuja, 2012; Radjou \& Prabhu, 2015). For example, Ansari, Munir and Gregg (2012) draw on the social capital and development literatures to suggest that business should engage with local organizations to build capacity in poor places, and Hall, Matos, Sheehan and Silvestre (2012) focus on the role of local innovation and the poor as entrepreneurs to achieve inclusive growth. Other promising research opportunities include how corporate organizations create value in poor places in the global north (much of the focus to date has been on the global south), how collaboration occurs at a micro level between corporates and community-based social 
purpose organizations, and how corporate innovation is constrained or enabled in different types of poor place.

\section{Cross-sectoral partnerships: social extrapreneurs and place-based social innovation}

In poor places, creating and working in and between organizations and networks is crucial to securing, sustaining and anchoring opportunity and resources. We recently suggested a framework to categorize social innovation (social entrepreneurship, social intrapreneurship and social extrapreneurship), which could provide a basis for theory building (Tracey \& Stott, 2017). We framed social extrapreneurship as the 'process of inter-organizational action that facilities alternative combinations of ideas, people, places and resources to address social challenges and make social change' (Tracey \& Stott, 2017, p. 55). For instance, the creation of support ecosystems, networks, funds and educational opportunities constitute forms of social extrapreneurship.

For NGOs, public organizations and corporate actors, social extrapreneurship is increasingly the means to achieve traction in extremely poor places, ensure legitimacy and offset poor governance practices (Simanis, 2012; Warren \& Visser, 2016). In Europe, the public sector has been a prime driver in orchestrating and funding social extrapreneurship activity within poor places through regeneration programmes, although systemic activity is in decline. In the USA, there has been a fascinating interplay between academia, foundations and the state, with foundations piloting social action underpinned by sociological research which was then picked up at scale by the Federal government; for instance, the rise of community-based organizations in the 1960s funded by the Ford Foundation and subsequently integral to the 'War on Poverty' (Marwell, 2007). Before the growth of the interventionist state, social extrapreneurship occurred through a mix of local public, church, civil, and social reformers - for instance settlements in poor places in the UK and USA 
delivered services as well as cajoled and catalysed inter-agency action from the late nineteenth century (Costa \& Pickering-Bernheim, 2014). The cooperative movement where inveterate social extrapreneurs locally and globally. In the UK, 'cooperative missionaries' spread the message town to town (Sanders, Marlow \& Marlow, 1913) and built infrastructure to support each other, education, journals and established a political party in 1917 to promote cooperative interests. The future challenge is to generate coherent social extrapreneurship strategies informed by practices (and research) past and present, which span sectors rather than the onus for action returning to the social sector.

Given small social or community enterprises face numerous hurdles to deliver sustainable missions, it might be assumed that social extrapreneurship activity would be a low priority. In fact, we would suggest it is often integral to micro organizational practices and vital to survival and impact. Poor places often have a plethora of mutual aid organizations down to street or housing block level. Not all are focused on the greater goodmany aim to defend territory or particular interests including criminal activities. The organizational landscape is often fractured, competitive and lacking in resources despite the best efforts of local social extrapreneurs including those provided by outside agencies such as religious organizations or community workers. Much of the recent academic interest and practitioner effort has focused on generating social capital, cohesion and collective responsibility - and now frequently labelled 'community resilience' - within poor places rather than understanding how they are embedded in, and constrained by, wider political and economic fields. In fact, the focus has been on poor individuals and their relationships with organizations rather than how organizations collectively produce and reproduce social life in poor places (Marwell, 2007). For Marwell, poor places are enabled or constrained primarily by external organizational actors and institutions, and the processes are 'hard to see and analyse.' Yet 'these organizations, their actors and their decisions, become visible if we make 
them the focus of analysis' $(2007$, p. 6). However, her three-year ethnographic study of community based organizations in Brooklyn does not entirely negate the agency of local actors. Marwell suggests that engaging with field level processes is crucial to securing organizational resources as well as encouraging powerful organizations to engage locally, such as by providing employment opportunities, improved health or education. This suggests that social extrapreneurship approaches which emphasize collaboration, 'foreign relations' and alliances (Suttles, 1972) to build complex relationships, influence and power locally are likely to be most effective in addressing deep rooted social problems. However, more work is needed to understand how such relationships are constructed and sustained.

The creation and delivery of impactful cross-sectoral partnerships appears to be particularly challenging in poor places partly because these practices are often underpinned by transactional relationships which are 'short termed, constrained and largely self-interest orientated rather than integrative partnerships' which are 'longer term, open ended and largely common-interest orientated' (Selsky \& Parker, 2010, p. 22). Unfortunately, shorttermism and self-interest appears to be a default position of many organizations across all sectors and of all sizes. In other words, while some organizations talk the cross-sector partnership talk, they fall very short in its execution. As Selsky and Parker point out, short termism and self-interest are not the only factors that inhibit cross-sector partnerships - lack of trust, transparency, skills and training also feature prominently.

Trust and transparency are often intertwined - organizational members tend to believe that members of other organizations are untrustworthy or self-serving if they do not understand those organizations and their inner workings (Schnackenberg and Tomlinson, 2016) . Often, the culture, language and context of different sectors are not mutually understood or appreciated, leading to organizations talking across rather than to each other (Smith and Schwegler, 2010) - a problem we are trying to address on a new Masters in Social 
Innovation that we set up at the University of Cambridge, which explicitly seeks to balance students with backgrounds from different sectors of the economy. Increasingly social entrepreneurs are spoilt for choice in opportunities to learn their craft through incubators, programmes delivered by practitioner organizations such as Ashoka as well as online and academic courses. Social intrapreneurs - people seeking to make change inside established organizations - can access a growing network through initiatives such as the League of Intrapreneurs $^{\text {viii }}$ and the Circle of Young Intrapreneurs ${ }^{\text {ix }}$. Similar initiatives for social extrapreneurs are less widely available. From an academic standpoint, what is currently lacking is a systematic understanding of the role of social extrapreneurship in social innovation - a role we suggest is crucial and requires urgent attention. In this respect, organizational and innovation researchers have a crucial role to play. In doing so, they might usefully connect not only with the literature on partnerships and alliances in management, but with other social scientists, including those working on social and political movements, empowerment, and communication (Servaes, Jacobson, \& White, 1996), and whose research speaks directly to the issues at the heart of social extrapreneurship.

\section{Conclusion}

Innovation matters in poor places. The alternative is stark. We have examined existing approaches to innovation in these contexts and proposed promising research directions. While the innovative capacity of poor places may well have been underestimated and more 'done by' innovation is to be welcomed, it is clear to us that sustainable and systemic solutions require cross sectoral collaboration and partnerships.

So, the dilemma remains that organizations within poor places need to incorporate social extrapreneurship into their repertoire, yet often start from a weak position in terms of capacity and power. Successful social extrapreneurship within poor places may begin with 
the forging of a shared vision by local organizations from all sectors, often with the catalytic support of external actors such as the state, NGOs or foundations, which can play a key role in supporting integrative cross-sector partnerships. An alternative (or complimentary) strategy is building out of, as well as within, poor places such as through the creation of intermediate organizations (like CDCs and cooperatives) which simultaneously provide support and engage with the powerful.

In conclusion, we suggest that innovation scholars can add value in three key areas. Firstly, assisting organizations by translating existing knowledge into their contexts. Secondly, extending existing knowledge through researching organizational innovation in poor places. Thirdly, following Puranam's call to action, 'prototyping and piloting new forms of organizing' (2017, p.5), including social extrapreneurship. 


\section{References}

Alinsky, S.D. (1965). The War on Poverty-Political Pornography. Journal of Social Issues Volume 21, Issue 1, 41-47

Amin, A., Cameron, A., \& Hudson, H. (2002). Placing the Social Economy. Routledge.

Ansari, S., Munir, K., \& Gregg, T. (2012). Impact at the 'Bottom of the Pyramid': The Role of Social Capital in Capability Development and Community Empowerment. Journal of Management Studies 49:4. 813-842

Arora, S., \& Romijn, H. (2011). The empty rhetoric of poverty reduction at the base of the pyramid. Organization 19(4) 481-505

Bailey, N. (2012). The role, organisation and contribution of community enterprise to urban regeneration policy in the UK. Progress in Planning 77. pp 1-35.

Battilana, J., \& Dorado, S. (2010). Building sustainable hybrid organizations: The case of commercial microfinance organizations. Academy of Management Journal, 53, 1419-1440.

Battilana, J., \& Lee, M. (2014). Advancing research on hybrid organizing-Insights from the study of social enterprises. The Academy of Management Annals, 8(1), 397-441.

Berkes, F., \& Ross, H. (2013). Community resilience: Towards an integrated approach. Society and natural resources 26. pp 5-20.

Cambridgeshire County Council. (2015). Stronger togeather: Cambridgeshire County Council's strategy for building resilient communities.

http://www.cambridgeshire.gov.uk/downloads/file/4176/community_resilience_strategy

Carroll, A. B., \& Shabana, K. M. 2010. The business case for corporate social responsibility: A review of concepts, research and practice. International Journal of Management Reviews, 12: 85-105.

Carter, C.R., \& Rogers, D.S. (2008) A framework of sustainable supply chain management: Moving toward new theory. International Journal of Physical Distribution \& Logistics Management, 38(5): pp. 360-387

Clegg, S. (2009). Bureaucracy, the Holocaust and Techniques of Power at Work. Management Revue. 20(4):326-347

Cole, G.D.H (1944) A Century of Cooperation. Manchester: Cooperative Union.

Costa, C.L., \& Pickering-Bernheim. (2014). Community economic development in social work. Columbia University Press.

Crisp, R., Pearson, M., \& Gore, T. (2015).Rethinking the impact of regeneration on poverty: a (partial) defence of a 'failed' policy Journal of Poverty and Social Justice, vol 23 no 3 167-87. http://dx.doi.org/10.1332/175982715X14443317211905

DeVerteuil, G. (2015). Resilience in the Post-welfare Inner City: Voluntary Sector Geographies in London, Los Angeles and Sydney.Policy Press. 
Dey, P., \& Teasdale, S. (2015). The tactical mimicry of social enterprise strategies: Acting 'as if' in the everyday life of third sector organizations. Organization, 23,485-504.

Di Domenico, M., Haugh, H., and Tracey, P. (2010) "Social bricolage: theorizing social value creation in social enterprises." Entrepreneurship Theory and Practice, 34(4): 681-703

DiMaggio, P.J., \& Powell, W.W. (1983).The Iron Cage Revisited: Institutional Isomorphism and Collective Rationality in Organizational Fields. American Sociological Review Vol. 48, No. 2 pp. 147-160

Dodgson, M., Gann, D.M., \& Philips, N. (2014). Perspectives on innovation management. In M. Dodgson., D.M Gann, \& N Philips (Ed), The Oxford Handbook of Innovation Management. Oxford.

Dunfee, T., \& Hess, D. (2000) "The Legitimacy of Direct Corporate Humanitarian Investment." Business Ethics Quarterly, 10(1): pp. 95-109

Gehrke, J.P. (2016) "A radical endeavour: Joseph Chamberlain and the emergence of municipal socialism in Birmingham." American Journal of Economics and Sociology, 75(1): pp. 23-57

George, G., McGahan, A.M., \& Prabhu, J. (2012). Innovation for Inclusive Growth: Towards a Theoretical Framework and a Research Agenda. Journal of Management Studies 49:4. Pp 661-683.

Gibson-Graham, J.K., Cameron .J., \& Healy, S. (2013). Take back the economy: An ethical guide for transforming our economies. Minnesota.

Giovannini, M. (2014). Indigenous community enterprises in Chiapas: a vehicle for buen vivir? Community Development Journal Vol 50 No 1 pp. $71-87$

Green, G.P., \& Haines, A.L. (2015). Asset Building \& Community Development. Sage $4^{\text {th }}$ Edition.

Gripaios, P. (2002). The Failure of Regeneration Policy in Britain, Regional Studies, 36:5, 568-577

Hall, J., Matos, S., Sheehan, L., \& Silvestre, B. (2012). Entrepreneurship and Innovation at the Base of the Pyramid: A Recipe for Inclusive Growth or Social Exclusion? Journal of Management Studies 49:4. Pp 785-812

Halpern, D. (2015). Inside the Nudge Unit: how small changes can make a big difference. Penguin.

Halpern, R. (1995). Rebuilding the inner city: A history of neighbourhood initiatives to address poverty in the United States. Columbia University Press.

Haugh, H. (2007). Community-led social venture creation. Entrepreneurship Theory and Practice, 31, 161-182.

Hatcher, D.L. (2016) The Poverty Industry: The Exploitation of America's most vulnerable citizens. New York University Press. 
Herrera, M. (2015). Creating competitive advantage by institutionalizing corporate social innovation. Journal of Business Research. 68 pp 1468-1474

Hess, D., Rogovsky., \& N. Dunfee, T.W. (2002) "The next wave of corporate community involvement: Corporate social initiatives." California Management Review, 44(2): pp. 110125.

Hess, D., \& Warren, D. (2008). The meaning and meaningfulness of corporate social initiatives. Business \& Society Review, 113(2): pp. 163-197.

Hildebrandt, T. (2013). Social Organizations and the Authoritarian State in China. Cambridge University Press.

Hockerts, K., \& Wüstenhagen, R. (2010) "Greening Goliaths versus emerging Davids theorizing about the role of incumbents and new entrants in sustainable entrepreneurship." Journal of Business Venturing, 25(5): pp. 481-492

Imbroscio, D.L. (1997). Reconstructing city politics: Alternative economic development and urban regimes. Sage

Imbroscio, D.L., Williamson, T., \& Alperovitz, G. (2003). Local Policy Responses to Globalization: Place-based ownership models of economic enterprise. The Policy Studies Journal. Vol.31.No 1. pp 31-52.

Jones, G.S. (1984/2013). Outcast London: A Study in the Relationship Between Classes in Victorian Society. Verso

Kanter, R. M. (1999). From spare change to real change. The social sector as beta site for business innovation. Harvard Business Review, 77:3, 122-132

Lawrence, T. B., Dover, G., \& Gallagher, B. (2014). Managing social innovation. In M. Dodgson., D. M. Gann., \& N. Phillips (Ed.), The oxford handbook of innovation management (pp. 316-334). Oxford: Oxford University Press.

Macek, S. (2006). Urban Nightmare: The Media, the Right and the Moral Panic over the City. Minnesota.

MacGregor, S.P., J. Fontradona., \& J. Hernandez (2010) 'Towards a Sustainable Innovation Model for Small Enterprises', in C. Louche., S.O. Idowu., \& W.L. Filho (eds.), Innovative CSR: From Risk Management to Value Creation. 305-30.Greenleaf Publishing

Mahoney, L. S., Thorne, L., Cecil, L., \& LaGore, W. (2013) "A research note on standalone corporate social responsibility reports: signalling or greenwashing?" Critical Perspectives on Accounting, 24(4-5): 350-359

Mair, J., Battilana, J., \& Cardenas, J. (2013). Organizing for Society: A Typology of Social Entrepreneuring models. Journal of Business Ethics 111.pp 353-373.

Mair, J., \& Marti, I. (2009) Entrepreneurship in and around institutional voids: A case study from Bangladesh. Journal of Business Venturing 24: 5. pp 419-435

Marwell, N.P. (2007) Bargaining for Brooklyn: Community Organizations in the Entrepreneurial City. University of Chicago Press.

Mazzucato, M. (2015). The Entrepreneurial State: De-bunking public vs private sector myths. Revised Edition. Anthem Press. 
Mintzberg, H. (2015). Rebalancing Society: Radical renewal beyond left, right \& centre. Berrett-Koehler

Mirvis, P., Herrera, M., Googins, B., \& Albareda, L. (2016). Corporate social innovation: How firms learn to innovate for the greater good. Journal of Business Research vol: 69 (11) pp: 5014-5021

Montgomery, A.W., Dacin, P.A., \& Dacin, M.T. (2012). Collective Social Entrepreneurship: Collaboratively Shaping Social Good. Journal of Business Ethics 111. pp 375-388.

Nwankwo, E., Phillips, N., \& Tracey, P. (2007) Social investment through community enterprise: the case of MNC involvement in the development of Nigerian water resources. Journal of Business Ethics, 73(1): 91-101

Pearce, J. (1993). At the heart of the community economy: Community enterprise in a changing world. Calouste Gulbenkian Foundation

Peredo, A.M., Anderson, R.B., Galbraith, C.S., Honig, B., \& Dana, L.P. (2004). Towards a theory of indigenous entrepreneurship. International. Journal of Entrepreneurship and Small Business. Vol. 1, Nos. 1/2, pp.1-20.

Peredo, A.M., \& Chrisman, J.T. (2006). Towards a Theory of Community-based Enterprise. Academy of Management Review, 31:2. pp 309-328

Porter, M. E., \& Kramer, M. R. (2011). Creating Shared Value: how to reinvent capitalism and unleash a wave of innovation and growth. Harvard Business Review, 89(1/2): pp. 62-77.

Power, S., Allouch, A., Brown, P., \&Tholen, G. (2016). Giving something back? Sentiments of privilege and social responsibility among elite graduates from Britain and France.

International Sociology. Vol. 31(3) 305-323

Prahalad, C.K., \& Hart, S.L. (2002).The Fortune at the Bottom of the Pyramid. strategy+business Issue 26.

Prahalad, C.K. (2004). The Fortune at the Bottom of the Pyramid: Eradicating Poverty through Profits. Wharton Business School Publishing.

Preuss, L. (2011). Innovative CSR: A framework for anchoring corporate social responsibility in the innovation literature. The Journal of Corporate Citizenship, (42), 17-33.

Puranam, P. (2017). When will we stop studying innovations in organizing, and start creating them? Innovation: Organization \& management. Vol 19, No 1, 5-10.

Radford, G. (2003) "From municipal socialism to public authorities: institutional factors in the shaping of American public enterprise." The Journal of American History, 90(3): pp. 863890.

Radford, G. (2013) The Rise of the Public Authority: Statebuilding and Economic Development in Twentieth-Century America. Chicago: University of Chicago Press.

Radjou, N., Prabhu, J., \& Ahuja, S. (2012) Jugaad innovation: think frugal, be flexible, generate breakthrough growth. Jossey-Bass.

Radjou, N, \&Prabhu J. (2015) Frugal innovation: how to do more with less. Profile. 
Robertson, N. (2016). The Co-operative Movement and communities in Britain 1914-1960: Minding their own business. Routledge.

Ross, H., \& Berkes, F. (2014). Research approaches for understanding, enhancing and monitoring community resilience. Society and natural resources 27, pp 787-804.

Sanders, R.M., Marlow, C., \& Marlow, J. (1913). Jubilee Souvenir of the Desborough Cooperative Society 1863-1913. Desborough Cooperative Society.

Schnackenberg, A.K., \& Tomlinson, E.C. (2016). Organizational Transparency: A New Perspective on Managing Trust in Organization-Stakeholder Relationships. Journal of Management Vol. 42 No. 7, November. pp $1784-1810$

Selsky, J.W., \& Parker, B. (2010). Platforms for Cross-Sector Social Partnerships: Prospective Sensemaking Devices for Social Benefit. Journal of Business Ethics. Vol 94. Supplement 1. pp 21-37.

Selznick. P. (1957). Leadership in Administration: A Sociological Interpretation. University of California Press.

Servaes, J., Jacobson, T.L., \& White, S.A. (eds.) (1996). Participatory Communication for Social Change. London: Sage.

Simanis, E. (2012). Reality check at the Bottom of the Pyramid. Harvard Business Review. June. pp 120-125.

Smith, W.K., Besharov, M., Wessels, A., \& Chertok, M. (2012). A Paradoxical Leadership Model for Social Entrepreneurs: Challenges, Leadership Skills, and Pedagogical Tools for Managing Social and Commercial Demands. Academy of Management Learning \& Education, 11: 463-478.

Smith, W., Gonin, M., \& Besharov, M. (2013). Managing Social-Business Tensions: A Review and Research Agenda for Social Enterprise. Business Ethics Quarterly, 23(3), 407442

Smith, L.R., \& Schwegler, U. (2010). The role of trust in international cooperation in crisis areas: a comparison between German and US-American Ngo partnership. In Saunders, M.N.K., Skinner, D., Dietz, G., Gillespie, N., \& Lewicki, R. J. (Eds) Organizational Trust. Cambridge University Press.

Smith, W. K., Leonard, H., \& Epstein, M. 2007. Digital divide data: A social enterprise in action. Harvard Business School Case Study

Somerville, P., \& McElwee, G. (2011). Situating community enterprise: A theoretical exploration. Entrepreneurship \& Regional development 23. No 506. pp 317 -330

Suttles, G.D. (1972). The Social Construction of Communities. University of Chicago Press.

Starbuck, W.H. (2003). Shouldn't organizational theory emerge from adolescence? Organization, 10, 3:439-452

Stephen, U., Uhlander, L.M., \& Stride, S. (2015) Institutions and social entrepreneurship: The role of institutional voids, institutional support, and institutional configurations. Journal of International Business Studies. 46. pp 308-331. 
Stinchcombe, A.L. (2002). New sociological microfoundations for organizational theory: A postscript. In M. Lounsbury, M. J. Ventresca (ed.) Social Structure and Organizations Revisited (Research in the Sociology of Organizations, Volume 19) Emerald Group Publishing Limited, pp.415 - 433

Stott, M., Stott, N.,\& Wiles, C. (2009). Learning from the past? Building community in new towns and growth areas. Keystone Development Trust.

Stott , N., \& Longhurst, N. (2011). Big Society and Poor Places. In M. Stott, (Ed), The Big Society Challenge (pp 100-110) Keystone Development Trust.

Tracey, P., \& Jarvis, O. (2006). "An enterprising failure." Stanford Social Innovation Review, 4(1): 66-70

Tracey, P., \&Phillips, N. (2016). Managing the consequences of organizational stigmatization: identity work in a social enterprise. Academy of Management Journal, 59:3. pp 740-765.

Tracey, P., \& Stott, N. (2017) Social innovation: a window on alternative ways of organizing and innovating. Innovation: Organization \& Management Vol19, No , 51-60.

Twelvetrees, A.C. (1996). Organizing for neighbourhood development: A comparative study of community based development organizations. Avebury.

Young Foundation. (2012). Adapting to change: The role of community resilience. Young Foundation.

Van der Have, R.P., \& Rubalcaba, L (2016). Social innovation research: An emerging area of innovation studies? Research Policy 45. Pp 1923-1935

Vogus, T.J., \& Sutcliffe, K.M (2007). Organizational resilience: Towards a theory and research agenda. IEEE International Conference on Systems, Man and Cybernetics

Warren, C., \& Visser, L. (2016). The Local Turn: An Introductory Essay Revisiting Leadership, Elite Capture and Good Governance in Indonesian Conservation and Development Programmes. Human Ecology, 44. 277-286

Wilson, J., Webster, A., \& Vorberg-Rugh, R. (2013) Building Co-operation: A Business History of The Co-operative Group, 1863-2013. Oxford: Oxford University Press

Willis, J. (2016). Locating Localism: Statecraft, citizenship and democracy. Policy Press. Wright, E.O. (2010). Envisioning Real Utopias. Verso 
' https://www.britishcouncil.org/society/social-enterprise

ii http://www.toms.co.uk/what-we-give

iii http://utmt.in/who-we-are/

iv http://vilcap.com/companies/

${ }^{v}$ http://www.thepowertochange.org.uk/

vi http://www.behaviouralinsights.co.uk/about-us/

vii http://www.100resilientcities.org/about-us\#/-_/

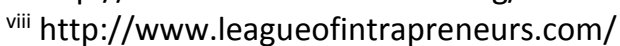

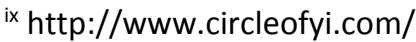

